Kumawula, Vol. 4, No.1, April 2021, Hal 79 - 86

DOI: https://doi.org/10.24198/kumawula.v4i1.31966

ISSN 2620-844X (online)

Tersedia online di http://jurnal.unpad.ac.id/kumawula/index

\title{
PROMOSI PREVENTIF SADARI (PERIKSA PAYUDARA SENDIRI) DI DESA SAYANG SEBAGAI UPAYA PENCEGAHAN KANKER PAYUDARA
}

\author{
Muchtaridi Muchtaridi ${ }^{* 1}$, Eli Halimah ${ }^{2}$, Sandra Megantara ${ }^{3}$,Nasrul Wathoni ${ }^{4}$ \\ ${ }^{1}$ Departemen Analisis Farmasi dan Kimia Medisinal, Fakultas Farmasi, Universitas Padjadajaran \\ ${ }^{2}$ Departemen Farmakologi dan Farmasi Klinik, Fakultas Farmasi, Universitas Padjadajaran \\ ${ }^{3}$ Departemen Analisis Farmasi dan Kimia Medisinal, Fakultas Farmasi, Universitas Padjadajaran \\ ${ }^{4}$ Departemen Farmaseutika dan Teknologi Farmasi, Fakultas Farmasi, Universitas Padjadajaran
}

*Korespondensi : muchtaridi@unpad.ac.id

\begin{abstract}
According to Globocan Data, International Agency for Research on Cancer (IARC) in 2018, breast cancer is one type of cancer that has a fairly high prevalence and the second leading cause of mortality worldwide, which is $11.6 \%$ or 2,089 million people and the morbidity ranks fifth with 6.6\% or 627,000 Million. In Indonesia, breast cancer mortality is ranked first at $16.7 \%$ or 58,256 million people and the morbidity rate is $11 \%$ or 22,692 million people. Breast self-examination is a self-examination of our breasts by learning independently through watching and checking the changes in their breasts every month. Periodic examinations will be able to detect lumps or even other problems from the start even though they are still small in size so that they are more effective to treat. The survey, pre-test, and post-test methods have been applied as an effort to promote awareness of family welfare empowerment $(P K K)$ to the members of PKK Sayang Village, Jatinangor Sub-district, Sumedang. Many Sayang Villagers had knowledge about breast cancer (68\%), but the lack of information about early prevention has resulted in a lack of awareness of health information including breast cancer prevention (58.82\%). The post-test results showed that SADARI preventive promotion program increased the knowledge and awareness of the community, so it was concluded that the community of Sayang Village needed to be promoted verbally so that knowledge and awareness would increase in preventing breast cancer.
\end{abstract}

Keywords: Early Detection, SADARI; Breast Cancer; Promotion

\begin{abstract}
ABSTRAK
Menurut Data Globocan International Agency for Research on Cancer (IARC) pada tahun 2018, kanker payudara merupakan salah satu jenis kanker yang mempunyai prevalensi cukup tinggi dan penyebab utama kedua mortalitas di seluruh dunia sebesar $11,6 \%$ atau 2.089 juta jiwa dan morbiditas menempati urutan ke-5 sebesar 6,6\% atau 627.000 juta jiwa. Di Indonesia, angka mortalitas kanker payudara menempati peringkat pertama sebesar 16,7\% atau 58.256 juta jiwa dan angka morbiditas sebesar $11 \%$ atau 22.692 juta jiwa. Periksa Payudara Sendiri (Sadari) adalah pemeriksaan payudara yang dilakukan kita sendiri dengan belajar mandiri yaitu melihat dan memeriksa perubahan payudaranya sendiri setiap bulan. Pemeriksaan yang dilakukan secara berkala akan membantu mengetahui adanya benjolan atau bahkan masalah lain dari sejak awal walaupun masih berukuran kecil sehingga lebih efektif untuk diobati. Metode survei, pre-test, dan post-test telah diterapkan sebagai upaya promosi Sadari ke ibu-ibu PKK Desa Sayang, Kecamatan Jatinangor, Sumedang. Masyarakat Desa Sayang dikatakan cukup tahu mengenai kanker payudara (68\%), namun kurangnya informasi tentang pencegahan dini mengakibatkan kesadaran terhadap informasi kesehatan termasuk tentang pencegahan kanker payudara menjadi kurang $(58,82 \%)$. Hasil post-test menunjukkan bahwa program promosi preventif Sadari meningkatkan pengetahuan dan kesadaran masyarakat sehingga disimpulkan bahwa masyarakat Desa Sayang perlu diberikan promosi secara berkala agar pengetahuan dan kesadaran meningkat dalam mencegah kanker payudara.
\end{abstract}

Kata Kunci: Deteksi Dini, Kanker Payudara; Promosi; SADARI 


\section{PENDAHULUAN}

Kanker merupakan salah satu penyebab kematian utama di dunia di mana mencakup sekitar 13\% dari seluruh kematian atau 7,6 juta kematian tahun 2016 dan diprediksi semakin meningkat hingga mencapai 13,1 juta kematian pada tahun 2030 (IARC, 2017). Indonesia merupakan negara yang menempati urutan ketiga kejadian penyakit kanker yang memiliki rasio insiden tertinggi di wilayah Asia Pasifik dengan angka insiden $12 \%$, setelah negara Cina (46\%) dan Jepang (14\%). Karenanya, salah satu kanker yang cukup tinggi prevalensinya adalah kanker payudara. Data Globocan International Agency for Research on Cancer pada tahun 2012 diketahui bahwa kanker payudara merupakan kanker yang paling banyak diderita oleh perempuan dengan jumlah 1,67 juta kasus baru $(43,1 \%)$ di dunia pada tahun 2012 dengan tingkat kematian 12,9\% (WHO, 2017). Kanker payudara merupakan salah satu penyakit kanker dengan prevalensi tertinggi di Indonesia dari tahun 2007 sampai 2016 dengan jumlah insiden sebanyak 611 kasus. Kalimantan Barat merupakan provinsi dengan tingkat prevalensi kanker payudara tertinggi dengan 265 kasus (Kementerian Kesehatan, 2017). Insiden pasien kanker payudara selalu meningkat tiap tahunnya, bahkan kanker payudara merupakan prevalensi kanker tertinggi di Indonesia. Pasien kanker payudara $60 \%$ mengeluh setelah terdeteksi pada stadium 3 ke atas, sehingga penyembuhan menjadi sulit dilakukan. Oleh karena itu, diperlukan pencegahan lebih dini dengan Periksa Payudara Sendiri (Sadari).

Pemeriksaan payudara anda sendiri atau disingkat Sadari secara berkala dapat menjadi aktivitas yang penting untuk mencegah secara dini menemukan kanker payudara sehingga kanker payudara cenderung berhasil diobati (Birnbaum, Duggan, Anderson, \& Etzioni, 2018; Wang, 2017). Titik paling kritis untuk penegakakan diagnosis adalah mengidentifikasi sel-sel kanker tahap awal (Wang, 2017). Meskipun memang tidak ada tes tunggal (hanya satu tes) yang dapat mendeteksi semua kanker payudara sejak awal. Perlu diyakinkan bahwa bahwa melakukan pemeriksaan payudara sendiri dalam kombinasi dengan metode skrining lainnya dapat meningkatkan kemungkinan deteksi dini. Apoteker yang berkecimpung dalam bidang onkologi memiliki peluang menarik untuk memimpin, memfasilitasi, dan mengadvokasi layanan pemeriksaan yang berkualitas dan menargetkan pada masyarakat secara individu (Coleman, 2017). Sadari dapat membantu keputusan akhir tentang penegakkan diagnosis kanker payudara dilakukan oleh dokter (Milosevic, Jankovic, Milenkovic, \& Stojanov, 2018). Promosi Sadari akan dilakukan di Desa Sayang, Jatinangor. Masyarakat Desa Sayang khsusunya perempuan kurang menyadari dengan bahaya penyakit kanker. Sebanyak 101 orang perempuan yang telah melewati pemeriksaan dinyatakan 5 orang positif menderita kanker payudara (Dahlan, 2017). Pasien yang diyatakan positif semuanya tidak sadar bahwa mereka telah terdeteksi kanker payudara. Desa Sayang merupakan salah satu desa yang berada di Kecamatan Jatinangor Kabupaten Sumedang Provinsi Jawa Barat, dengan jumlah penduduk sekitar 8.876 orang dan dengan jumlah kepala keluarganya sebanyak $2.513 \mathrm{KK}$, desa ini terdiri dari 13 RW dan 48 RT. Berdasarkan hasil survei, salah satu permasalahan kesehatan di Desa Sayang adalah kurangnya pengetahuan dan kesadaran terhadap informasi kesehatan termasuk tentang pencegahan kanker payudara.

Oleh karena itu, perlu dibangkitkan kesadaran dari kelompok sasaran karena merekalah yang dapat mengubah perilaku dan menyebarkan informasi yang diterima kepada orang lain (Narulita et al., 2019). Maka, untuk menyebarkan informasi, tim melakukan kegiatan sosialisasi. Sosialisasi sendiri merupakan proses belajar dengan orang lain mengenai cara bertindak, berpikir, dan merasakan sehingga akan muncul partisipasi sosial yang efektif (Sekarningrum, Sugandi, \& Yunita, 2020). Dengan demikian, diharapkan sosialisasi terkait promosi program Sadari dapat menjadi upaya preventif mencegah kanker payudara yang dilakukan setelah penelitian survei. 


\section{METODE}

Teknik penelitian survei digunakan dalam mendapatkan data pada kegiatan pengabdian masyarakat ini. Pengabdian masyarakat dilaksanakan pada bulan JuniAgustus 2019. Data primer diperoleh dari ibuibu PKK yang mengikuti sosialisasi melalui wawancara langsung dengan menggunakan kuesioner sebagai alat bantu yang telah dipersiapkan sebelumnya. Sedangkan data sekunder diperoleh dari dinas atau intansi yang terkait dengan penelitian ini dan dari hasil penelitian sebelumnya. Penelitian dilaksanakan di Desa Sayang, Kecamatan Jatinangor, Kabupaten Sumedang.

Metode dalam melaksanakan program pengabdian kepada masyarakat ini terdiri dalam tiga tahap, yaitu prapelaksanaan, tahap pelaksanaan, dan pascapelaksanaan.

Pada tahap prapelaksanaan kegiatan terdiri dari:

1. Survei tingkat desa dan kecamatan

2. Penentuan tempat sosialisasi dan promosi Sadari

3. Mempersiapkan alat-alat bantu promosi Sadari

Tahap pelaksanaan dilakukan hal-hal beikut:

1. Kuesioner tentang pengetahuan Kanker Payudara

2. Sosialisasi dan promosi Sadari

3. Pre-test dan post-test

Instrumen penelitian ini menggunakan kuesioner serta pre-test dan post-test yang diberikan kepada 102 responden dengan berbagai karakter responden.

Responden hanya diminta untuk memberikan tanda centang $(\sqrt{ })$ pada jawaban yang dianggap sesuai dengan responden. Skala dalam kuesioner ini dapat diberikan jawaban yang pasti yaitu menggunakan tanda centang "benar dan salah". Persamaan dipakai untuk mengukur presentase jawaban responden terhadap kuesioner menurut Arikunto (2013), yaitu:

Persentase $=\frac{\text { Jumlah yang benar }}{\text { Jumlah soal }} \times 100 \%$

\section{HASIL DAN PEMBAHASAN}

\section{A. Aspek Demografis}

Survei dilakukan di Desa Sayang, Kecamatan Jatinangor, Kabupaten Sumedang, dengan pengambilan sampel sebanyak 102 responden perempuan dengan simple random sampling. Karakteristik responden penelitian diperlihatkan dalam Tabel Suplemen dari artikel ini. Responden terbanyak berusia antara 35-40 tahun dengan jumlah 33 orang dan responden yang paling sedikit berusia 15-19 tahun dengan jumlah 6 orang. Tingkat pendidikan responden terbanyak yaitu SMA dengan jumlah 40 orang dan paling sedikit yaitu D1 sebanyak 1 orang. Hal itu menunjukan bahwa umumnya pendidikan terakhir warga Desa Sayang yaitu SMA.

Pekerjaan responden terbanyak yaitu sebagai ibu rumah tangga dan yang paling sedikit bekerja sebagai wiraswasta, buruh, dan pegawai negeri. Hal ini menunjukan bahwa pada umumnya pekerjaan perempuan warga Desa Sayang yaitu sebagai ibu rumah tangga. Responden yang sudah menikah dengan jumlah 86 orang dan yang paling sedikit telah bercerai dengan jumlah 5 orang.

Responden yang berpenghasilan dibawah 10 juta pertahun adalah yang terbanyak yaitu berjumlah 61 orang, sedangkan yang paling sedikit berjumlah 1 orang yang berpenghasilan antara $40-60$ juta per tahun. Menurut Kelley et al., identifikasi responden perlu ditentukan untuk menentukan kualitas survei (Kelley et al., 2003). Misalnya, umur sangat berpengaruh pada pengalaman responden dalam mengisi survei (Chang et al., 2018)

\section{B. Aspek Pengetahuan}

Kanker payudara merupakan jenis kanker yang bermula dari sel-sel yang ada di 
Tabel 1. Indikator Penilaian Aspek Pengetahuan Kanker Payudara

\begin{tabular}{clcc}
\hline No. & Indikator & \multicolumn{2}{c}{ Kisaran Skor } \\
& & Benar & Salah \\
\hline 1. & Pengetahuan umum kanker payudara & 80 & 22 \\
2. & Pengetahuan faktor risiko kanker payudara & 98 & 4 \\
3. & Pengetahuan gejala/tanda kanker payudara & 80 & 22 \\
4. & Pengetahuan pencegahan kanker payudara & 62 & 40 \\
& Rata-Rata & 80 & 22 \\
\hline
\end{tabular}

Tabel 2. Data Aspek Pengetahuan Kanker Payudara

\begin{tabular}{ccccc}
\hline Pertanyaan & \multicolumn{2}{c}{ Jawaban } & Total & Persentase \\
& Benar & Salah & & \\
\hline 1 & 102 & 0 & 102 & $100 \%$ \\
2 & 49 & 53 & 102 & $48 \%$ \\
3 & 91 & 11 & 102 & $89 \%$ \\
4 & 48 & 54 & 102 & $47 \%$ \\
5 & 72 & 30 & 102 & $71 \%$ \\
6 & 86 & 16 & 102 & $84 \%$ \\
7 & 67 & 35 & 102 & $66 \%$ \\
8 & 43 & 59 & 102 & $42 \%$ \\
9 & 48 & 54 & 102 & $47 \%$ \\
10 & 54 & 48 & 102 & $53 \%$ \\
11 & 56 & 46 & 102 & $55 \%$ \\
12 & 77 & 25 & 102 & $75 \%$ \\
13 & 58 & 44 & 102 & $57 \%$ \\
14 & 35 & 67 & 102 & $34 \%$ \\
15 & 68 & 34 & 102 & $67 \%$ \\
16 & 79 & 53 & 132 & $60 \%$ \\
17 & 77 & 25 & 102 & $75 \%$ \\
18 & 89 & 13 & 102 & $87 \%$ \\
19 & 74 & 28 & 102 & $73 \%$ \\
20 & 95 & 7 & 102 & $93 \%$ \\
21 & 62 & 40 & 102 & $61 \%$ \\
22 & 56 & 46 & 102 & $55 \%$ \\
23 & 99 & 3 & 102 & $97 \%$ \\
24 & 96 & 6 & 102 & $94 \%$ \\
25 & 79 & 23 & 102 & $77 \%$ \\
Rata-rata & & & & $\mathbf{6 8} \%$ \\
\hline
\end{tabular}

payudara. Kanker ini merupakan jenis kanker yang paling sering terjadi di kalangan perempuan. Menurut penelitian tahun 2018, sekitar $13 \%$ kematian disebabkan kanker payudara sehingga kanker ini menjadi salah satu penyebab kematian utama di dunia (DeSantis et al., 2017). Oleh karena itu, dilakukan survei dengan pemberian kuesioner kepada 102 responden masyarakat Desa Sayang. Survei ini dilakukan bertujuan untuk mengadakan kegiatan sosialisasi kepada kalangan ibu-ibu Desa Sayang perihal mengenal dan mencegah kanker payudara didukung dengan pelaksanaan Sadari. 
Untuk mengetahui tingkat pengetahuan dasar kalangan ibu-ibu masyarakat Desa Sayang mengenai kanker payudara, disusun dan disebarkan kuesioner yang berisikan beberapa pertanyaan yang mewakili indikator pengetahuan mengenai kanker payudara dengan empat indikator penilaian seperti yang tercantum Tabel 1.

Setelah menyebarkan kuesioner, terdapat 102 responden yang mengisi beberapa pertanyaan di bagian aspek pengetahuan. Kuesioner terdiri dari 25 pertanyaan yang mewakili 4 aspek tersebut terhadap 102 responden. Hasil yang diperoleh dari pengolahan data kuesioner aspek pengetahuan kepada 102 responden adalah berdasarkan data Tabel 2, skor pengetahuan responden tergolong cukup. Hal ini didasarkan kategorisasi tingkat pengetahuan menurut Arikunto (2013) bahwa nilai $\geq 76-100 \%$ dikategorikan baik, sedangkan kategori cukup jika nilainya 60-75 \% dan tingkat pengetahuan kategori kurang memiliki nilai $\leq 60 \%$.

\section{Aspek Kesadaran}

Setelah menganalisis pada aspek pengetahuan kanker payudara bagi masyarakat Desa Sayang, perlu dilakukan analisis serupa pada aspek kesadaran mengenai pencegahan kanker payudara. Ini dilakukan sejalan dengan topik pengabdian masyarakat terkait dengan promosi Sadari atau Periksa Payudara Sendiri sehingga adanya keterkaitan sebagai salah satu cara pencegahan dari kanker payudara.

Adapun di bagian aspek kesadaran pencegahan kanker payudara, kami membaginya menjadi dua, yaitu analisis terhadap persepsi dan analisis terhadap motif (alasan) tidak melakukan pencegahan kanker payudara.

\section{Persepsi tentang Pencegahan Kanker Payudara}

Berdasarkan hasil kedua tabel (Tabel 3 dan 4) di atas dapat dilihat bahwa persepsi kesadaran ibu-ibu Desa Sayang mengenai pencegahan kanker payudara berada pada tingkat sedang, hal ini ditunjukkan dengan persentase yang mencapai angka 58,82\%. Ibuibu Desa Sayang setuju bahwa kanker payudara dapat dicegah, mengetahui pencegahan kanker payudara, pernah melakukan pencegahan kanker payudara secara medis dan sangat setuju bahwa penting diadakannya program pencegahan kanker payudara kepada masyarakat. Kurangnya kesadaran akan deteksi dini kanker payudara juga terjadi di Thailand. Sebagian besar perempuan migran di Thailand

Tabel 3. Indikator Penilaian Bagian Persepsi Pencegahan Kanker Payudara

\begin{tabular}{clc}
\hline No. & Pertanyaan & Kisaran Skor \\
\hline 1 & Kanker payudara dapat dicegah & $1-2$ \\
2 & Saya mengetahui pencegahan kanker payudara & $1-5$ \\
3 & Saya pernah melakukan pencegahan kanker payudara & $1-5$ \\
4 & Pencegahan kanker payudara dilakukan secara medis & $1-4$ \\
5 & Pencegahan kanker payudara dapat dilakukan melalui metode tradisional dan & $1-4$ \\
& spiritual & $1-2$ \\
6 & Menurut saya penting diadakannya program pencegahan kanker payudara & \\
& kepada masyarakat & $\mathbf{6 - 2 2}$ \\
\hline
\end{tabular}

Tabel 4. Hasil Penilaian Bagian Persepsi Pencegahan Kanker Payudara

\begin{tabular}{ccccc}
\hline No. & Tingkat Persepsi & Nilai & Jumlah (orang) & Persentase \%) \\
\hline 1 & Rendah & $6 \leq \mathrm{x} \leq 11,33$ & 29 & 28,43 \\
2 & Sedang & $11,33 \leq \mathrm{x} \leq 16,33$ & 60 & 58,82 \\
3 & Tinggi & $16,33 \leq \mathrm{x} \leq 21,99$ & 13 & 12,75 \\
& Jumlah & & $\mathbf{1 0 2}$ & $\mathbf{1 0 0}$ \\
\hline
\end{tabular}


tidak merasa bahwa mereka berisiko terkena kanker payudara. Meskipun melihat program skrining kanker payudara sebagai hal yang penting, para wanita jarang memerhatikan skrining kanker payudara. Hambatan termasuk lokasi layanan, pola penyediaan layanan kesehatan yang tidak dikenal, dan kesulitan bahasa menjadi kendala (Suwankhong dan Liamputtong, 2018).

\section{Motif Tidak Melakukan Pencegahan Kanker Payudara}

rendah. Alasan utama rendahnya partisipasi adalah sikap budaya terhadap praktik deteksi dini kanker payudara, terutama merasa malu untuk mengekspos payudara mereka kepada orang lain. Parsa et al., (2006) dan Marmot et al., (2013) mengemukakan bahwa jika individu tidak peduli untuk terlibat dalam program untuk deteksi kanker payudara secara dini, peluang mereka untuk bertahan hidup mungkin lebih rendah karena kanker mereka tidak dapat didiagnosis lebih awal.

Tabel 5. Indikator Penilaian Bagian Motif Tidak Melakukan Pencegahan Kanker Payudara

\begin{tabular}{llc}
\hline No & \multicolumn{1}{c}{ Pertanyaan } & Kisaran Skor \\
\hline & Saya tidak melakukan pencegahan kanker payudara, karena : \\
1 & Saya pikir ini memalukan & $0-5$ \\
2 & Saya tidak ingin diperiksa oleh dokter laki-laki & $1-4$ \\
3 & Saya menghindari rasa takut dan cemas & $2-4$ \\
4 & Saya lupa & $2-4$ \\
5 & Saya pikir biayanya mahal & $1-4$ \\
6 & Saya merasa sedang tidak menderita kanker & $0-4$ \\
7 & Saya pikir itu tugas pemerintah & $0-4$ \\
8 & Selama suami tidak tahu atau keluarga tidak risau & $0-4$ \\
& Jumlah & $6-33$
\end{tabular}

Tabel 6. Hasil Penilaian Bagian Motif Tidak Melakukan Pencegahan Kanker Payudara

\begin{tabular}{ccccc}
\hline No & Tingkat Motif & Nilai & Jumlah (orang) & Persentase (\%) \\
\hline 1 & Rendah & $6 \leq x \leq 15$ & 80 & 78,43 \\
2 & Sedang & $15 \leq x \leq 24$ & 22 & 21,56 \\
3 & Tinggi & $24 \leq x \leq 33$ & 0 & 0 \\
& Jumlah & & 102 & 100 \\
\hline
\end{tabular}

Hasil Tabel 5 dianalisis menggunakan Tabel 6. Berdasarkan hasil kedua tabel (5 dan 6) di atas dapat dilihat bahwa pendapat ibu-ibu Desa Sayang terhadap pencegahan kanker payudara berada pada tingkat sedang, hal ini ditunjukkan dengan persentase yang mencapai angka 78,43\% kategori rendah. Sebagian besar ibu-ibu Desa Sayang setuju bahwa tidak melakukan pencegahan kanker payudara dikarenakan tidak ingin diperiksa oleh dokter laki-laki, menghindari rasa sakit dan cemas, serta tidak ingin keluarga risau. Namun, tren umum dalam hal jumlah untuk deteksi dini kanker payudara di antara wanita Asia (yaitu Malaysia, Iran, Yordania dan Cina) relatif

\section{PRE-TEST \& POST TEST}

Setelah terdapat pengolahan data kuesioner, kelompok kami juga tidak lupa untuk melakukan pre-test dan post test pada hari kegiatan sosialisasi "Mengenali dan Mencegah Kanker Payudara". Ini dilakukan dengan tujuan untuk menguji tingkat pengetahuan kanker payudara dan kesadaran pencegahan kanker payudara kepada responden yang menghadiri kegiatan sosialisasi tersebut. Adapun berikut ini hasil data pre-test dan post test yang diperoleh dari 57 responden yang hadir terihat pada Tabel 7. Berdasarkan data pada Tabel 7 dapat dilihat bahwa hasil antara pre-test dan post test sangat signifikan. Nilai rata-rata pengetahuan 
mengenai kanker payudara sebelum promosi adalah $35,33 \%$, sedangkan setelah dipaparkan mengenai promosi preventif kanker payudara mencapai nilai rata-rata $66,15 \%$. Tabel 8 yang diolah menggunakan software SPSS, menunjukkan bahwa adanya korelasi antara pre-test dan post test. keyakinan yang mempengaruhi kinerja perilaku kesehatan.

Namun, Sadari ini pun tidak dapat direkomendasikan sebagai tindakan kesehatan masyarakat untuk mengendalikan kanker payudara. Pengendalian kanker payudara selanjutnya harus ditegakkan dengan diagnosis yang dikawal oleh dokter (WHO, 1984).

Tabel 7. Data Hasil Pre Test dan Post Test

\begin{tabular}{ccccc}
\hline No. & Nama & $\begin{array}{c}\text { Jumlah } \\
\text { Peserta }\end{array}$ & $\begin{array}{c}\text { Rata-rata } \\
\text { Pre Test }\end{array}$ & $\begin{array}{c}\text { Rata-rata } \\
\text { Post Test }\end{array}$ \\
\hline 1 & RW 01 & 8 & $6 \pm 1,2$ & $8 \pm 0,8$ \\
2 & RW 04 & 8 & $5 \pm 0,9$ & $6 \pm 0,3$ \\
3 & RW 05 & 8 & $3 \pm 0,5$ & $7 \pm 0,5$ \\
4 & RW 06 & 8 & $4 \pm 0,8$ & $5 \pm 0,6$ \\
5 & RW 10 & 8 & $3 \pm 0,6$ & $6 \pm 0,3$ \\
6 & RW 06 & 8 & $2 \pm 0,5$ & $8 \pm 0,8$ \\
7 & RW 08 & 8 & $5 \pm 1,0$ & $5 \pm 0,8$ \\
8 & RW 09 & 8 & $4 \pm 0,9$ & $5 \pm 0,4$ \\
9 & RW 07 & 8 & $4 \pm 0,7$ & $5 \pm 0,3$ \\
10 & RW 10 & 8 & $3 \pm 0,6$ & $7 \pm 0,5$ \\
11 & RW 13 & 8 & $3 \pm 0,7$ & $8 \pm 0,6$ \\
12 & RW 15 & 7 & $2 \pm 0,4$ & $7 \pm 0,5$ \\
13 & RW 17 & 7 & $2 \pm 0,6$ & $9 \pm 0,6$ \\
& Total & $\mathbf{1 0 2}$ & $\mathbf{3 5 , 3 3 \%}$ & $\mathbf{6 6 , 1 5} \%$ \\
\hline
\end{tabular}

Tabel 8. Nilai Korelasi antara Pre-test (x) dan Post-test (y)

\begin{tabular}{cccc}
\hline \multicolumn{3}{c}{ Correlations } & $\mathrm{Y}$ \\
\hline & & $\mathrm{X}$ & 0,118 \\
$\mathrm{X}$ & Pearson Correlation & 1 & 0,756 \\
& Sig. (2-tailed) & & 57 \\
$N$ & 57 & 1 \\
& Pearson Correlation & 0,118 & \\
Sig. (2-tailed) & 0,756 & 57 \\
$N$ & 57 &
\end{tabular}

Melihat perbandingan antara pre-test dan post test tersebut, maka diperoleh kesimpulan bahwa pemberian materi promosi preventif dapat memberikan dampak besar terhadap ibu-ibu baik mengenai gejala, pemeriksaan, pencegahan, bahkan pengobatan. Karena itu, edukasi yang diberikan hendaknya tidak dilakukan hanya sekali saja, namun perlu dilakukan beberapa kali sehingga masyarakat terkhususnya kepada kalangan ibu di Desa Sayang menjadi lebih paham. Menurut Salazar (1993), program pendidikan yang efektif membutuhkan pemahaman tentang sikap dan

\section{KESIMPULAN}

Masyarakat Desa Sayang ini masih cukup dikatakan kurang paham mengenai kanker payudara. Kurangnya pengetahuan dan kesadaran terhadap informasi kesehatan ini termasuk kurangnya pengetahuan tentang pencegahan kanker payudara. Promosi Sadari (Periksa Payudara Sendiri) diberikan sebagai upaya preventif pencegahan kanker payudara telah meningkatkan pengetahuan dan kesadaran masyarakat Desa Sayang. 


\section{UCAPAN TERIMA KASIH}

Terima kasih kepada Rektor Universitas Padjadjaran yang telah membantu kegiatan pengabdian ini melalui ALG 2019. Kami ucapkan terima kasih kepada mahasiswa KKN Periode Juli-Agustus 2019 Desa Sayang atas nama Afif dan kawan-kawan.

\section{DAFTAR PUSTAKA}

Arikunto, S. (2013). Prosedur Penelitian Suatu Pendekatan Praktik. Jakarta: Rineka Cipta.

Birnbaum, J. K., Duggan, C., Anderson, B. O., \& Etzioni, R. (2018). Early detection and treatment strategies for breast cancer in low-income and upper middle-income countries: a modelling study. The Lancet. Global health, 6(8), e885-e893.

Coleman, C. (2017). Early Detection and Screening for Breast Cancer. Seminars in Oncology Nursing, 33(2), 141-155.

Dahlan, A. (2017). Penderita Kanker Serviks dan Payudara di Sumedang Patut Diwaspadai. In, vol. 2019). Sumedang: Radio Republik Indonesia.

IARC. (2017). Breast Cancer Estimated Incidence, Mortality and Prevalence Worldwide in 2012. In). New York: IARC.

Kementerian Kesehatan, K. R. (2017). Data dan Informasi Profil Kesehatan Indonesia 2016. In K. K. R. Indonesia (Ed.)). Jakarta: Kementerian Kesehatan Republik Indonesia.

Marmot, M. G., Altman, D. G., Cameron, D. A., Dewar, J. A., Thompson, S. G., \& Wilcox, M. (2013). The benefits and harms of breast cancer screening: an independent review. $\mathrm{Br} J$ Cancer, 108(11), 2205-2240.

Milosevic, M., Jankovic, D., Milenkovic, A., \& Stojanov, D. (2018). Early diagnosis and detection of breast cancer. Technol Health Care, 26(4), 729-759.

Narulita, A., Fajar, C. M., Riesma, R. S. N., Rachman, J. B., Aditiany, S., \& Dipura, D. S. (2019). Sosialisasi Citra Baru Pencak Silat sebagai Soft Power Indonesia Kepada Siswa SMP Negeri 2 Kota Bandung. Jurnal Kumawula:
Jurnal Pengabdian Kepada Masyarakat, 2(1), 72-92.

https://doi.org/http://10.24198/kumawul a.vli3.23461

Parsa, P., Kandiah, M., Abdul Rahman, H., \& Zulkefli, N. M. (2006). Barriers for breast cancer screening among Asian women: a mini literature review. Asian Pacific journal of cancer prevention : APJCP, 7(4), 509-514.

Salazar, M. K. (1993). [Health promotion. Evaluation of breast cancer detection beliefs using a decision model]. Kanhohak Tamgu, 2(2), 66-78.

Sekarningrum, B., Sugandi, Y. S., \& Yunita,

D. (2020). SOSIALISASI DAN

EDUKASI KANGPISMAN

(KURANGI, PISAHKAN DAN

MANFAATKAN SAMPAH).

Kumawula: Jurnal Pengabdian Kepada Masyarakat, 3(1).

Suwankhong, D., \& Liamputtong, P. (2018). Early Detection of Breast Cancer and Barrier to Screening Programmes amongst Thai Migrant Women in Australia: A Qualitative Study. Asian Pacific journal of cancer prevention : APJCP, 19(4), 1089-1097.

Wang, L. (2017). Early Diagnosis of Breast Cancer. Sensors (Basel, Switzerland), 17(7), 1572.

WHO. (2017). World Health Statistics 2017 : Monitoring Health for the SDGs. In): World Health Organization.

World Health Organization, W. (1984). Selfexamination in the early detection of breast cancer: memorandum from a WHO meeting. Bulletin of the World Health Organization, 62(6), 861-869. 